Buca Eğitim Fakültesi Dergisi, 2021, Say1 51, s.119-136

Araştırma Makalesi
The Journal of Buca Faculty of

Education, 2021, Issue 51, p.119-136

Original Research

\title{
Çocukların Kariyer Gelişiminde Ebeveyn Desteği ve Sosyo-demografik Özelliklerin Rolü*
}

\section{The Role of Parental Support and Socio-Demographics Variables on Children's Career Development}

\author{
Vedat BAKIR ${ }^{l}$, Ayşenur BÜYÜKGÖZE KAVAS ${ }^{2}$
}

\begin{abstract}
${ }^{1}$ Öğretim Görevlisi, Çocuk Gelişimi, Kütahya Dumlupınar Üniversitesi, Türkiye, vedat.bakir@dpu.edu.tr, (https://orcid.org/0000-0001-5458-5110)

${ }^{2}$ Doç. Dr., Eğitim Bilimleri Bölümü, Rehberlik ve Psikolojik Danışmanlık, Ondokuz Mayıs

Üniversitesi, Türkiye, aysenur@omu.edu.tr, (https://orcid.org/0000-0000-0001-9072-7040)
\end{abstract}

Geliş Tarihi: 13.08.2020

Kabul Tarihi: 27.02.2021

\section{ÖZ}

Bu araştırmanın amacı ilköğretim 7. ve 8.sınıf öğrencilerinin kariyer gelişimlerini ebeveyn desteği ve sosyo-demografik değişkenler açısından incelemektir. Araştırma verileri, 2017-2018 eğitim öğretim yılında bir ilçedeki ilköğretim 7. ve 8.sınıfta öğrenim görmekte olan 1288 öğrenciden toplanmıştır. Verilerin toplanmasında, Kişisel Bilgi Formu, Çocuklar İçin Kariyer Gelişim Ölçeği ve Kariyere İlişkin Ebeveyn Desteği Ölçeği (KIEDÖ) kullanılmıştır. Araştırmanın bulgularına göre kız öğrencilerin bilgi, merak, denetim odağı, zaman perspektifi, benlik kavramı, sözel teşvik ve duygusal destek puanları erkek öğrencilerden anlamlı derecede yüksek; erkek öğrencilerin ise anahtar figür ve kariyere ilişkin modelleme düzeylerinin daha yüksek olduğu bulunmuştur. Sınıf düzeyine göre incelendiğinde ise 8.sınıflarda bilgi ve denetim odağı düzeyleri 7.sınıf öğrencilerinden anlamlı derecede yüksek bulunmuştur. Ancak araçsal yardım boyutunda 7.sınıf öğrencilerinin düzeyleri 8 . sınıf öğrencilerinin düzeyinden daha yüksek bulunmuştur. Gidilmesi hedeflenen lise türüne göre en yüksek puanların sırasıyla Fen, Anadolu/İmam Hatip, Meslek lisesi şeklinde olduğu görülmektedir. Bitirilmek istenen en son okul için en yüksek puandan en düşük puana doğru doktora, yüksek lisans, lisans, önlisans ve lise sonucuna ulaşılmıştır.

Anahtar Kelimeler: Kariyer psikolojik danışmanlığı, çocuklarda kariyer gelişimi, ebeveyn desteği.

\begin{abstract}
The aim of this study is to examine the career development in terms of parental support and sociodemographic variables. The research data were collected from 1288 students attending in the 7 th and 8th grades of primary education in the 2017-2018 academic year. The data were collected by Personal Information Form, Career Development Scale for Children, and Career-Related Parental Support Scale. According to the findings, female students' knowledge, curiosity, locus of control, time perspective, selfconcept, verbal encouragement, and emotional support scores were significantly higher than male students; male students were found to have higher levels for key figures and careers. When analyzed by grade level, knowledge and locus of control levels in 8th grades were significantly higher than 7th grade students; Instrumental help levels of 7 th grade students were also found higher. According to the type of high school that wants to go, the highest scores were seen as Science, Anatolia / Imam Hatip, Vocational High School,
\end{abstract}

\footnotetext{
* Bu makale birinci yazarın ikinci yazar danışmanlığında yürüttüğü yüksek lisans tezinden üretilmiştir.
} 
respectively. For the last school to be completed, the highest scores were obtained for the doctorate, graduate, undergraduate, and high school respectively.

Keywords: Career counseling, career development in children, parental support.

\section{GíRiş}

Mesleki rehberlik ve kariyer psikolojik danışmanlığı, psikolojik danışmanlık ve rehberlik alanının başlangıç noktası olmakla birlikte tarihsel anlamda da alanın temel yapı taşı olarak görülmektedir. Kariyer psikolojik danışmanlığı uzmanlık alanının önemi bireyin yaşamındaki meslek/iş olgusuna yönelik; terapötik bilgi ve becerileri de içeren profesyonel yardım hizmetlerinden kaynaklanmaktadır. Kariyer gelişimi sürecinde bireyin farkındalık kazanma, eğitim olanaklarını öğrenme, ilgi ve yeteneklerini keşfetme, geleceğe yönelik iş fırsatlarını değerlendirme gibi kariyere yönelik karar verme ve yol haritası belirlemeyle ilgili rehberlik edecek önemli konularda çeşitli beceriler edinmelerine yardımcı olmak amaçlanır (Özyürek, 2013).

Kariyer gelişim süreci bireyin doğumundan itibaren başlayıp ölümüne kadar devam eden bir süreç olarak görülmesine (Ginzberg, Ginsburg, Axelrad ve Herma, 1951; Super, 1990) rağmen ortaöğretim öncesi dönemde kariyer gelişimine ilişkin çalışmaların ülkemizde oldukça sınırlı değişkenlerle yapıldığı görülmektedir (Altay Köse ve Yangın, 2015; Bacanlı ve Sürücü, 2011; Bozgeyikli, Bacanl1, ve Doğan, 2009; Can ve Tayl1, 2014; Gelişli, Kazykhankyzy ve Shauyenova, 2018; Işık, 2014; Özdemir Yaylacı, 2007). Kariyer gelişimine yönelik yapılan araştırmaların birçok özellik bakımından daha çok lise ve üniversite öğrencileri üzerine yoğunlaştığ1 görülmektedir (Akkoç, 2009; Alkan, 2014; Dinç, 2008; Korkut Owen, 2018; Nalbantoğlu Y1lmaz ve Çetin Gündüz, 2018; Öztemel, 2013; Pekkaya ve Çolak, 2013; Şeker ve Kaya, 2018). Oysaki kariyer gelişimi çocukluk yıllarından itibaren şekillenmeye başlayan bir süreçtir. $\mathrm{Bu}$ nedenle çocukların kariyer gelişim sürecine yaşam boyu gelişim bakış açısı ile bakılması durumunda kariyer gelişiminde yaşanan sorunları saptama ve bu sorunları çözüme ulaştırmada sağlayacağı katkılar ile beraber ruh sağlığına olumlu destek verileceği söylenebilir (Eryllmaz ve Mutlu, 2017).

Gelişimsel açıdan bakıldığında yaşam boyu devam eden bir süreç olan kariyer gelişiminin ilköğretim yıllarını da kapsadığı görülmektedir. Eğitim öğretim etkinliklerinin ilk yılları olan ilköğretim dönemi, çocukların kariyere yönelik tutumlarının ve davranışlarının geliştiği ve kariyer karar verme yetkinliklerinin oluştuğu bir dönem olarak karşımıza çıkmaktadır (Bozgeyikli, Bacanlı, ve Doğan, 2009). İlköğretim dönemi meslek ve kariyer gelişiminin yanı sıra kişilik gelişimi açısından da önemlidir. Benlik tasarımı, içsel denetim, güven ve kendini kabul gibi kişilik boyutlarıyla beraber gelişen tutum, değer ve algılar kariyer ve mesleki gelişim açısından önemli görülmektedir (Özgüven, 2003). İlköğretim öğrencilerinin henüz küçük yaşta kariyere ilişkin kesin adımlar atması ve meslek seçmeleri beklenmez; ancak kişisel özelliklerinin farkında olması, iş ve meslek dünyasını tanıması, karar verme stratejileri geliştirmesi, hedef belirlemesi, ilgi ve tutumlarının oluşması, toplumsal değerlerini anlaması ve üst eğitim kurumlarını seçmesi beklenen kariyer davranışlarıdır (Can ve Taylı, 2014; Kuzgun, 2008).

Kritik dönem olarak nitelendirilen çocukluktaki kariyer gelişimi birçok etmenden etkilenmektedir (Bacanlı ve Torun, 2012). Çocukların kariyer gelişimini etkileyen faktörler psikolojik, sosyolojik, cinsiyet, ekonomik ve politik faktörler şeklinde sınıflandırabilir (Pişkin, 2012). Toplumun en küçük yapı taşı olarak nitelendirilen aile bu faktörlerin içeriğini oluşturan sosyal bir kurum olarak nitelendirilebilir. Ailenin ekonomik durumu, demografik özellikleri, başta anne baba olmak üzere aile fertlerinin eğitim seviyesi, ailenin ve içinde bulunduğu çevrenin sosyo-ekonomik ve kültürel özellikleri kariyer gelişimini olumlu ya da olumsuz yönde etkileyebilmektedir (Whiston ve Keller, 2004). Kariyer gelişimi sürecinde çocuğa verilen 
ebeveyn desteği açısından anne babanın bilinçlilik düzeyi belirleyici bir rol oynamaktadır. Anne babanın bilinçlilik düzeyi ise eğitim seviyesi ile bağlantılı görülmektedir (Güneş, 2015). Ailedeki kardeş sayısı, çocukların yaşları, aile içi iletişim, anne baba tutumları da diğer etkili unsurlardır. Anne baba tutumları özellikle mesleki karar verme sürecinde yönlendirme, bilgi toplama, motive etme, zengin uyarıcılar sağlama ve deneyimleme açısından önemli görülmektedir (Kesici, 2005; Whiston ve Keller, 2004). Bu doğrultuda ebeveynlerin çocuklarının eğitim öğretim süreçlerindeki yardım ve desteği araçsal yardım anlamında önem teşkil etmektedir. Bunun yanında çocukların gelişim süreçlerinde mesleki anlamda örnek alacağ ve taklit edebileceği kariyere ilişkin rol modeller de çocukların bakış açılarına zenginlik katmaktadır. Bununla birlikte çocukları sözel olarak motive etmek ve duygu paylaşımında bulunarak güven vermek sosyal ve duygusal destek bakımından önemli görülmektedir.

Anne babaların çocuklarının kariyer gelişimlerine destek olabilmeleri için kariyer süreçlerini iyi bilmeleri gerekmektedir. Ebeveynler kariyer konusunda yeterli bilgi sahibi olmadıklarında çocuklarını yanlış yönlendirecek ve gerçek anlamda destek olamayacaklardır. Anne babaların öncelikle çocuklarını tanıması; ilgi, yetenek ve tutumlarını keşfetmeleri gerekmektedir. Günümüzde anne babalar çocuğun özelliklerini göz ardı ederek toplumsal değerlere ağırlık veren bir anlayışla kendi isteklerine göre yönlendirme yapabilmektedir (Kapkıran, 2016). Ebeveynler tarafindan yapılan bu yönlendirme çocukta direnç oluşturduğunda ise baskı kurarak çocuğu zorlamaya kadar gidebilmektedir. Bu durum zamanla "ebeveyn başarı baskısı" hâlini alarak çocuğu başka çocuklarla kıyaslamaya ve rekabete teşvik edebilmektedir. Bask1 durumu çocuğun kariyer gelişimini olumsuz etkilediği gibi ruh sağlı̆̆ açısından da utangaçlık, özgüven eksikliği, kin ve düşmanlık gibi olumsuz sonuçlar doğurmaktadır. Baskının dışında ihmalkâr ve ilgisiz anne baba tutumları da görülebilmektedir (Aslan, Yalçın, Sarp ve Akarçay Uluçay, 2018). Anne baba, çocuğun kariyer gelişimine ilgisiz kaldığında ise gerekli yönlendirmeler ve destek sağlanamadığından çocuğun yeteneklerini geliştirici ortam sunulamamaktadır. $\mathrm{Bu}$ nedenle kariyer psikolojik danışmanlığı alanında kariyer gelişim sürecinde anne baba desteğinin istendik yönde olması oldukça önemlidir. Ailenin özelliklerinin yanı sıra ailenin cinsiyet algısı da kariyer gelişimini etkileyen faktörler arasında yer almaktadır. $\mathrm{Bu}$ algı aile fertlerinin mesleklere yönlendirilmesinde etkili olmaktadır. Bu açıdan baktığımızda erkeklerle kıyaslandığında, kadın sayısı mühendislik, mekanik, imalat sanayi ve yönetim işleri gibi alanlarda anlamlı bir biçimde farklılık göstermektedir (Korkut-Owen ve Mutlu, 2016; Özyürek, 2013). İşgücü istihdamının bu şekilde farklılaşmasında aile temelinde toplumsal cinsiyet rolleri, toplumsal yargılar ve kalıp düşünceler etkili olmaktadır.

Kariyer gelişimini ve meslek seçimini açıklamaya yönelik birçok kuram ve model önerilmiştir. Çocukların kariyer gelişimi söz konuşu olduğunda özellikle gelişimsel yaklaşımların ön plana çıktığı söylenebilir. İlk olarak Ginzberg, Ginsburg, Axelrad ve Herma (1951), kariyer gelişimine ilişkin genç yetişkinlik dönemine kadar farklı yaş dönemleri için farklı kariyer gelişim görevleri tanımlanmıştır. Bu dönemler, fantezi dönemi (5-11 yaş), deneme dönemi (11-17 yaş) ve gerçekçi dönem (17-23 yaş) olarak isimlendirilmiştir. Sonrasında ise Super $(1957$; 1990) kariyer gelişiminin belirli bir yaş ile sınırlandırılamayacağını belirterek kariyerin durağan bir süreçten ziyade dinamik bir süreç olarak görülmesini sağlayarak kariyer sürecine farklı bir yön kazandırmıştır. Super kariyer gelişim sürecini büyüme dönemi ( $0-14$ yaş), keşfetme dönemi (14-24 yaş), yerleşme dönemi (25-44 yaş), sürdürme dönemi (45-65 yaş) ve geri çekilme dönemi (65 ve sonrası) olmak üzere beş dönem halinde incelemiştir. Özellikle okula başlama çağı olan büyüme dönemine ve okul çağı olan keşfetme dönemine dikkat çekmiştir. Büyüme döneminde, bireyin bedensel gelişiminin yanı sıra bilişsel, duygusal ve sosyal beceri anlamında da gelişimin olduğu dönemdir. Çocuğun okula başlamasıyla birlikte etkileşimleri artmaya başlar; meslek kavramları kazanarak benliği ile ilişki kurmaya başladığı dönemdir (Super, 1990). Keşfetme döneminde ise birey yetenek, ilgi ve değerler konusunda farkındalık kazanmaya başlar. Geleceğe ilişkin konularda gerçekçi tercihlerde bulunabilir. Birey okula başlama çağından itibaren toplumsal normları ve kendisinden beklenilen görevleri fark etmeye başlar (Sapmaz, 2010). Bu süreçte benlik kavramı da biçimlenmektedir. Okulla birlikte 
sosyal yaşama da adım atan çocuk etrafını gözlemleyerek sosyal çevresi yardımıyla meslekler arasında bağlantı kurmaya başlar. Kurulan bağlantılar sayesinde aynı zamanda hayallerin de etkisiyle mesleklere ilişkin fikirler, anlamlar, değerler, ilgiler ve tutumlar da oluşmaktadır. Özellikle hayale dayalı oyunlar aracıllğıyla çocuğun büründüğü roller mesleklerin görev ve sorumluluklarını da çocuğa yaşatmaktadır (Tuzcuoğlu, 2000). Çocuk ergenlik dönemine doğru ilerlerken içinde bulunduğu toplumu, zamanı ve imkânlarını da sorgulamaya başlar. Artık hayaller yerini gerçekçi düşüncelere bırakmaya başlamıştır. Çocuğun yeteneklerinin yanı sıra ilgileri doğrultusunda mesleki yönelimleri gerçeğe doğru evrilmeye başlar. Mesleki yönelimleri çizgisinde birey, farklı seçenekleri değerlendirerek kariyer planları belirler ve hedeflerine yönelik becerileri edinmeye başlar (Sapmaz, 2010).

Super (1990) 4-14 yaş arası çocukluk dönemi kariyer gelişiminin ihmal edildiğini öne sürerek kariyer olgunluğu ile ilgili ilk modelini oluşturmuştur. Bu teorik modelde; merak, araştırma, bilgi, anahtar figürler, ilgiler, denetim odağı, zaman perspektifi, benlik kavramı ve planlama olmak üzere dokuz boyut bulunmaktadır. Merak, çocuğun kendisi ve çevresi hakkında bilgi edinmek amacıyla araştırma ve inceleme etkinliklerinde bulunmasıdır. Bilgi ise mesleklerle ilgili bilgi edinmeyi ve edilen bilginin nasıl kullanılacağ ile farkındalık kazanmayı ifade eder. Anahtar figür, faydalı ve yararlı görülen rol modeldir. İlgiler ise bireyin hoşlandığ veya hoşlanmadığı şeylerdir. Denetim odağı, bireyin bugünün ve yarının üzerindeki kontrol hissini ifade eder. Zaman perspektifi bireyin geçmişin, bugünün ve yarının planlamasında zaman algısının oluşmasıdır. Benlik algısı ise bireyin biyolojik özellikleri, toplumsal rolleri ve diğer insanlarla olan etkileşiminin bütünüdür. Planlama ise kısaca kariyer basamaklarında beklenilen yol gösterici faaliyetlerdir. Belirtilen dokuz boyutun davranışları sadece meslek seçimine değil aynı zamanda kariyer gelişimine, sağlıklı karar verme mekanizmalarına ve diğer gelişim alanlarına da katkı sunmaktadır. Bu nedenle bu boyutların geliştirilmesine yönelik yapılacak çalışmalar çocukların kariyer gelişimi sürecine ve kişilik gelişimine önemli katkılar sunacaktır.

Ülkemizde uygulanan zorunlu eğitim politikasının bir parçasının ilköğretim dönemi olmasına karşılık ilgili alanyazına baktığımızda sınırlı çalışmaların olduğu görülmektedir. Yapılan çalışmanın okul psikolojik danışmanlığına ve kariyer gelişim sürecindeki paydaşlara kariyeri etkileyen faktörlerin anlamlandırılması bakımından faydalı olacağı düşünülmektedir. Özellikle değişen dünya şartları ve küreselleşme boyutunun eğitime yansımalarıyla birlikte okul çeşitliliğinin artmasına sebep olmuştur. Ortaöğretim seçeneklerinin şekillenmeye başladığ ilköğretimin son yılları daha da önem kazanmış olup mesleki olgunluk açısından da ilerlemenin meydana geldiği düşünülmektedir. $\mathrm{Bu}$ nedenle, bu araştırma, ilköğretim 7. ve 8. sinıf öğrencilerinin kariyer gelişiminde ebeveyn desteği ve sosyo-demografik değişkenlerin rolünü incelemeyi amaçlamaktadır. Ayrıca, çocukların kariyer gelişim düzeyleri cinsiyet, sınıf, yaş, kardeş sayısı, anne baba durumu, gelir düzeyi, gidilmek istenen lise türü, en son bitirilmek istenen okul düzeyi açısından da incelenmiştir.

\section{YÖNTEM}

\subsection{Araștırma Grubu}

Araştırma, ilköğretim 7. ve 8. sınıf öğrencilerinin kariyer gelişim düzeylerinin ebeveyn desteği ile birlikte; cinsiyet, sınıf düzeyi, kardeş sayısı, yaş, anne babanın birlikte/ayrı/sağ olma durumu, algılanan sosyoekonomik düzeyi, gitmek istediği ortaöğretim kurumu ve en son bitirilmek istenen eğitim kurumu gibi yönlerden incelemek amacıyla yapılmıştır. Araştırmada basit tesadüfi örnekleme yöntemi ile örneklem seçimine gidilerek betimsel tarama modeli kullanılarak veri toplanmıştır. Araştırmanın çalışma grubu, 2017-2018 eğitim öğretim yılında, bir ilçede öğrenim gören 7. ve 8. sınıf 1288 (693'ü kız 595'i erkek) öğrencilerinden oluşmaktadır. Araştırmaya katılan öğrencilerin demografik özellikleri Tablo 1'de gösterilmektedir. 
Tablo 1. Araştırmaya Katılan Öğrencilerin Sosyo-Demografik Özellikleri

\begin{tabular}{llll}
\hline Demografik Değişken & Faktör & $\mathrm{N}$ & $\%$ \\
\hline \multirow{2}{*}{ Cinsiyet } & Kız & 693 & 53.8 \\
Sinıf & Erkek & 595 & 46.2 \\
& 7. sınıf & 625 & 48.5 \\
& 8. sınıf & 663 & 51.5 \\
Yaş & 12 yaş & 189 & 14.7 \\
& 13 yaş & 612 & 47.5 \\
Anne Baba Birlikte Mi? & 14 yaş & 452 & 35.1 \\
& 15 yaş & 35 & 2.7 \\
& Evet & 1237 & 96 \\
Algılanan Sosyo-ekonomik düzey & Hayır & 51 & 4 \\
& Düşük & 121 & 9.4 \\
& Ortanın Altı & 185 & 14.4 \\
& Orta & 872 & 67.7 \\
& Ortanın Üstü & 92 & 7.1 \\
& Yüksek & 18 & 1.4 \\
& Fen Lisesi & 531 & 41.2 \\
Gidilmek İstenen Lise Türü & Anadolu Lisesi & 451 & 35 \\
& Meslek Lisesi & 116 & 9 \\
& İmam Hatip Lisesi & 160 & 12.4 \\
& Sosyal Bil. Lisesi & 22 & 1.6 \\
& Diğer & 8 & 0.6 \\
& Lise & 117 & 9.1 \\
& 2 Yılllk MYO & 46 & 3.6 \\
& Üniversite & 511 & 39.7 \\
& Yüksek Lisans & 310 & 24.1 \\
& Doktora & 304 & 23.6 \\
\hline
\end{tabular}

Tablo 1 incelendiğinde araştırmaya katılan öğrencilerin \% 53,8'nin kız, \% 46,2'nin ise erkek olduğu görülmektedir. Sınıf düzeyleri açısından bakıldığında \% 48,5'i 7.sınıf, \% 51,5'nin ise 8.sınıf olduğu görülmektedir. Katılımcıların yaşlarına baktığımızda sırasıyla en çok \% 47,5 oran ile 13 yaş grubu, \% 35,1 ile 14 yaş grubu olduğu görülmektedir. Katılımcıların kendileri dâhil kardeş sayısına bakıldığında \% 61,4' nün 4-6 kardeş oldukları görülmektedir. Katılımcıların $\%$ 96'sının annesi ve babasının birlikte olduğu görülmektedir. Gelir düzeylerine bakıldığında $\% 67,7$ 'si orta gelir düzeyine sahip olduğu görülmektedir. Gitmek istenen lise türüne bakıldığında sırasıyla en çok \% 41,2 ile fen lisesi ve \% 35 ile anadolu lisesi olduğu görülmektedir. Bitirilmek istenen eğitim programına bakıldığında \%87,3'ü en az lisans mezunu olmak istemekte ve \% 23,6's1 ise doktora mezunu olmayı istemektedir.

\subsection{Veri toplama Araçları}

Bu çalışmada, ilköğretim 7. ve 8. sınıf öğrencilerinin sosyo-demografik bilgilerine ulaşmak amacıyla Kişisel Bilgi Formu ile kariyer gelişim düzeylerine ilişkin Çocuklarda İçin Kariyer Gelişimi Ölçeği (ÇKGÖ; Bacanlı, Özer, ve Sürücü, 2006) ve ebeveyn desteğini ölçmek amacıyla da Kariyere İlişkin Ebeveyn Desteği Ölçeği (KİEDÖ; Güneş, 2015) kullanılmıştır.

\subsubsection{Kişisel Bilgi Formu}

Cinsiyet, yaş, okul, sınıf, kardeş sayısı, ebeveyn durumu, algılanan sosyoekonomik düzeyi, gidilmek istenen ortaöğretim kurumu ve en son bitirilmek istenen eğitim kurumu bilgilerini içeren 11 maddeden oluşmaktadır.

\subsection{2. Çocuklar için Kariyer Gelişimi Ölçeği (ÇKGÖ)}

Schultheiss ve Stead (2004) tarafından ilköğretim öğrencilerinin kariyer gelişimlerini ölçmek amacıyla geliştirilen ölçek Türkçeye Bacanl, Özer ve Sürücü (2004) tarafindan uyarlanmıştır. Ölçeğin teorik yapısı Super'ın (1990) oluşturmuş olduğu kariyer gelişimi modeline 
dayanmaktadır. Toplamda 52 maddeden oluşan ÇKGÖ 3'lü likert tipi (bana uygun, bana biraz uygun, bana uygun değil) puanlamaya sahip olup ölçekten alınan yüksek puan kariyer gelişim düzeyinin yüksek olduğunu ifade etmektedir.

Türkçeye uyarlanan ÇKGÖ’ ünün yapı geçerliliğini belirlemek amacıyla yapılan açıklayıcı ve doğrulayıcı faktör analizleri sonucunda orijinalinde olduğu gibi bilgi, merak, ilgiler, denetim odağı, anahtar figürler, zaman perspektifi, planlama ve benlik kavramları olmak üzere sekiz alt boyuttan oluştuğu görülmüştür (Bacanll, Özer, Sürücü, 2006). ÇKGÖ’nün güvenirliği ve iç tutarlılık katsayıları hesaplandığında ölçeğin tümü ve alt ölçekleri için Cronbach Alpha değerleri; ölçeğin tümü için .78, bilgi alt boyutu için .64, merak/araştırma alt boyutu için .60, ilgiler alt boyutu için .64, denetim odağ1 alt boyutu için .76, anahtar figürler alt boyutu için .49 , zaman perspektifi alt boyutu için .65 , planlama alt boyutu için .81 ve benlik kavramı alt boyutu için .73 olduğu rapor edilmiştir (Bacanlı, Özer, ve Sürücü, 2006). Ayrıca ÇKGÖ’nün güvenirliği için ÇKGÖ'nün tümüne ve alt ölçeklerine ilişkin test-tekrar test kararlılık katsayıları hesaplanmıştır. Buna göre korelasyon değerleri ÇKGÖ toplam puan için. $68,(p<.001)$, bilgi alt boyutu için .51( $p$ $<.001)$, alt boyutu için merak .64, $(p<.001)$, ilgiler alt boyutu için $.34(p<.001)$, denetim odağ alt boyutu için $.39(p<.001)$, anahtar figürler alt boyutu için $.50,(p<.001)$, zaman perspektifi alt boyutu için .43, $(p<.001)$, planlama alt boyutu için .66, $(p<.001)$ ve benlik kavramı alt boyutu için.32, $(p<.001)$ olarak hesaplanmıştır.

\subsubsection{Kariyere İlişskin Ebeveyn Desteği Ölçeği (KİEDÖ)}

Kariyer gelişimine ilişkin anne baba desteğini ölçmek amacıyla 2003 yılında Turner, Brissett, Lapan, Udipi ve Ergun tarafından geliştirilen KİEDÖ'nün Türkçe uyarlaması Güneş (2015) tarafindan yapılmıştır. KİEDÖ, araçsal yardım, kariyere ilişkin modelleme, sözel teşvik ve duygusal destek olmak üzere dört alt ölçekten ve toplamda 27 maddeden oluşmaktadır. Ölçekten alınan en yüksek puan 135, en düşük puan 24' dir. Ölçekten alınan yüksek puanlar ebeveyn desteğinin yüksek olduğunu ifade etmektedir (Güneş, 2015).

KİEDÖ ile toplanan verilere uygulanan DFA sonucunda uyum katsayılarının $(\chi 2 / \mathrm{sd}=2.46$, RMSEA $=0.05$, SRMR $=0.05$, AGFI $=0.98$ ) literatürde önerilen uyum katsay1larıla karşılaştırıldığında iyi düzeyde olduğu görülmektedir. KİEDÖ’nin, güvenirliğini ölçmeye yönelik uygulanan Cronbach'ın Alpha iç tutarlık katsayısı ve test-tekrar test tekniği uygulanıp kararlılık katsayısı hesaplanmıştır. Cronbach Alpha iç tutarlık katsayısı ölçeğin tümü için .93, Araçsal Yardım alt ölçeği için .81, Kariyere İlişkin Modelleme alt ölçeği için .87, Sözel Teşvik alt ölçeği için .82, Duygusal Destek alt ölçeği için .83 olarak bulunmuştur. Ayrıca ölçek 7. ve 8.sınıfta okuyan 43 öğrenciye 28 gün ara ile tekrar uygulanmıştır. KİEDÖ'nün test-tekrar test yöntemiyle hesaplanan kararlılık katsayısı ölçeğin tümü için .90, Araşsal Yardım alt ölçeği için .87, Kariyere İlişkin Modelleme alt ölçeği için .96, Sözel Teşvik alt ölçeği için .90, Duygusal Destek alt ölçeği için ise .90 olarak bulunmuştur.

\subsection{Veri Analizi ve İşlem}

Araştırma kapsamında Kişisel Bilgi Formu, Çocuklar İçin Kariyer Gelişim Ölçeği ve Kariyere İlişkin Ebeveyn Desteği Ölçeği etik kurul izni ve ilçe milli eğitim müdürlüğünün izni ile okul müdürlükleri tarafından öğrencilere uygulanmıştır. Araştırma verileri ilk araştırmacı tarafindan SPSS 22 programı kullanılarak bilgisayar ortamına aktarılmış ve veri analizine hazır hâle getirilmiştir Normallik analizleri sonucunda 1288 öğrenci verileri üzerinden araştırma yürütülmüştür. Araştırmada betimsel istatistikler; frekanslar/yüzdelikler hesaplanarak sosyodemografik dağılımları gösteren sayısal veriler elde edilmiştir. Araştırmada iki gruplu değişkenlerin karşılaştırılmasında İlişkisiz Örneklemler $t$-Testi, ikiden fazla gruplar için Tek Yönlü Varyans Analizi (ANOVA) uygulanmıştır. Algılanan ebeveyn desteğinin kariyer gelişimini yordayıp yordamadığını incelemek için regresyon analizi yapılmıştır. Yapılan analizlere ek olarak Pearson Korelasyon Katsayıları hesaplanmıştır. 


\section{BULGULAR}

Araştırmanın bu bölümünde "Kişisel Bilgi Formu", "Çocuklar İçin Kariyer Gelişim Ölçeği”" ve "Kariyere İlişkin Ebeveyn Desteği Ölçeği” ile elde edilen verilerin karşılaştırılmasına yönelik veri analizlerine yer verilmektedir. ÇKGÖ ve KİEDÖ'nün alt boyutları arasındaki ilişkiler Pearson Momentler Çarpımı korelasyon katsayısı ile hesaplanarak Tablo 2'de verilmiştir.

Tablo 2. Ölçeklerin Alt Boyutlarına İlişkin Korelasyon Katsayıları

\begin{tabular}{|c|c|c|c|c|c|c|c|c|c|c|c|}
\hline 12 & 1 & 2 & & 3 & 4 & 5 & 6 & 7 & 9 & 10 & 1 \\
\hline 1.Bilgi & - & & & & & & & & & & \\
\hline 2.Merak Araştırma & $.43^{* *}$ & - & & & & & & & & & \\
\hline 3.İlgiler & $.21^{* *}$ & $.24^{* *}$ & - & & & & & & & & \\
\hline 4.Denetim Odağ 1 & $.23^{* *}$ & $.24^{* *}$ & $.29^{* *}$ & - & & & & & & & \\
\hline 5.Anahtar Figürler & $.24^{* *}$ & $.25^{* *}$ & $.26^{* *}$ & $.19^{* *}$ & - & & & & & & \\
\hline 6.Zaman_Perspektifi & $.31^{* *}$ & $.30^{* *}$ & $.37^{* *}$ & $.25^{* *}$ & $.27^{* *}$ & - & & & & & \\
\hline 7.Planlama & $.33^{* *}$ & $.40^{* *}$ & $.35^{* *}$ & $.26^{* *}$ & $.33^{* *}$ & $.46^{* *}$ & - & & & & \\
\hline 8.Benlik_Kavramı & $.24^{* *}$ & $.28^{* *}$ & $.47^{* *}$ & $.32^{* *}$ & $.38^{* *}$ & $.44^{* *}$ & $.48^{* *}$ & - & & & \\
\hline 9.Araçsal_Yardım & $.20^{* *}$ & $.22^{* *}$ & $.14^{* *}$ & $.08^{* *}$ & $.15^{* *}$ & $.16^{* *}$ & $.21^{* *}$ & $.17^{* *}$ & - & & \\
\hline 10.Kariyere_iliş. M. & $.12^{* *}$ & $.11^{* *}$ & $.10^{* *}$ & .04 & $.18^{* *}$ & $.11^{* *}$ & $.13^{* *}$ & $.07^{*}$ & $.52^{* *}$ & - & \\
\hline 11.Sözel_Teşvik & $.14^{* *}$ & $.19^{* *}$ & $.17^{* *}$ & $.12^{* *}$ & $.06^{*}$ & $.15^{* *}$ & $.17^{* *}$ & $.17^{* *}$ & $.68^{* *}$ & $.40^{* *}$ & \\
\hline 12.Duygusal_Destek & $.18^{* *}$ & $.24^{* *}$ & $.13^{* *}$ & $.09^{* *}$ & $.13^{* *}$ & $.18^{* *}$ & $.22^{* *}$ & $.18^{* *}$ & $.71^{* *}$ & $.49^{* *} .74^{* *}$ & - \\
\hline $\bar{X}$ & 16.10 & 17.28 & 16.67 & 17.85 & 11.32 & 10.78 & 28.17 & 16.022 & 22.74 & 20.5421 .02 & 23.44 \\
\hline Ss & 1.96 & 2.47 & 1.78 & 2.82 & 2.25 & 1.49 & 4.22 & 2.03 & 6.27 & 7.115 .94 & 6.92 \\
\hline
\end{tabular}

Çocuklar İçin Kariyer Gelişim Ölçeği alt boyutlarından alınabilecek en yüksek puanlar sırasıyla "bilgi" alt boyutu için 18, "merak" alt boyutu için 21, "ilgiler" alt boyutu için 18, "denetim odağı" alt boyutu için 21, "anahtar figürler" alt boyutu için 15, "zaman perspektifi" alt boyutu için 12, "planlama" alt boyutu için 33 ve "benlik kavramı" alt boyutu için 18' dir. Kariyere İlişkin Ebeveyn Desteği Ölçeği alt boyutlarından alınabilecek en yüksek puanlar sırasıyla "araçsal yardım" 35, "kariyere ilişkin modelleme" 35, "sözel teşvik" 30 ve "duygusal destek" boyutu 35' dir.

Tablo 3. İlköğretim Öğrencilerinin Kariyer Gelişimine İlişkin Adımsal Regresyon Analizi Sonuçları

\begin{tabular}{|c|c|c|c|c|c|c|}
\hline \multirow{4}{*}{$\begin{array}{l}\text { Model } \\
1 \text { (Sabit) } \\
\text { Araçsal Yardım }\end{array}$} & \multicolumn{2}{|c|}{$\begin{array}{l}\text { Standardize Edilmemiş } \\
\text { Katsayılar }\end{array}$} & \multirow{2}{*}{$\begin{array}{l}\text { Standardize } \\
\text { Edilmiş } \\
\text { Katsayılar } \\
\text { Beta }\end{array}$} & \multirow[b]{2}{*}{$t$} & \multicolumn{2}{|c|}{ Korelasyonlar } \\
\hline & B & Std. Hata & & & & \\
\hline & 122.581 & 1.240 & & 98.825 & & \\
\hline & .512 & .053 & .262 & 9.746 & .262 & .262 \\
\hline 2 (Sabit & 122,079 & 1.298 & & 94.033 & & \\
\hline Araçsal Yardım & .470 & .062 & 241 & 7.637 & 208 & 205 \\
\hline Kariyere İlişskin Mod & .071 & .054 & .041 & 1.304 & .036 & 035 \\
\hline 3 (Sabit) & 120.911 & 1.372 & & 88.125 & & \\
\hline Araçsal Yardım & .350 & .077 & 179 & 4.550 & .126 & .122 \\
\hline Kariyere İlişkin Mod & .060 & .054 & .035 & 1.112 & .031 & .030 \\
\hline Sözel Teşvik & .196 & .076 & .095 & 2.585 & .072 & .069 \\
\hline
\end{tabular}




\begin{tabular}{|c|c|c|c|c|c|}
\hline 4 (Sabit) & 120.614 & 1.370 & & 88.014 & \\
\hline Araçsal Yardım & .260 & .082 & .133 & 3.168 & .088 \\
\hline Kariyere İlişkin Mod & .030 & .055 & .017 & .538 & .015 \\
\hline Sözel Teşvik & .057 & .087 & .028 & .656 & .018 \\
\hline Duygusal Destek & .252 & .079 & .142 & 3.174 & .088 \\
\hline 5 (Sabit) & 111.795 & 6.139 & & 18.212 & \\
\hline Araçsal Yardım & .264 & .080 & .135 & 3.290 & .092 \\
\hline Kariyere İlişkin Mod & .033 & .054 & .019 & .610 & .017 \\
\hline Sözel Teşvik & -.038 & .086 & -.018 & -.443 & -.012 \\
\hline Duygusal Destek & .236 & .078 & .133 & 3.041 & .085 \\
\hline Yaş & .643 & .438 & .039 & 1.467 & .041 \\
\hline Gitmek İsten Lise & -1.365 & .306 & -.125 & -4.462 & -.124 \\
\hline Türü & 1.501 & 298 & .142 & 5.038 & .139 \\
\hline $\begin{array}{l}\text { Bitirmek İstediği } \\
\text { Okul }\end{array}$ & & & & & \\
\hline
\end{tabular}

Adımsal regresyon analizinin birinci adımında incelenen "araçsal yardım" değişkeninin öğrencilerin kariyer gelişimini yordamada standardize edilmiş regresyon katsayısı .262 çıkmıştır. Tek başına "araçsal yardım" değişkeninin öğrencilerin kariyer gelişimini yaklaşık olarak \%7 kadarını $\left(\mathrm{R}^{2}=.069\right)$ açıkladığı görülmektedir.

Adımsal regresyon analizinin ikinci adımında modele "araçsal yardım" değişkeninin yanında "kariyere ilişkin modelleme" değişkeni girmiştir. "araçsal yardım" ve "kariyere ilişkin modelleme" değişkenleri birlikte öğrencilerin kariyer gelişimini \%7'sini $\left(\mathrm{R}=.265, \mathrm{R}^{2}=.070\right)$ açıklamaktadır.

Adımsal regresyon analizinin üçüncü adımında modele "araçsal yardım", "kariyere ilişkin modelleme" değişkenlerinin yanında "sözel teşvik" değişkeni girmiştir. "araçsal yardım", "kariyere ilişkin modelleme" ve "sözel teşvik" değişkenleri birlikte öğrencilerin kariyer gelişimini $\% 8$ 'sini $\left(\mathrm{R}=.274, \mathrm{R}^{2}=.075\right)$ açıklamaktadır.

Adımsal regresyon analizinin dördüncü adımında modele "araçsal yardım", "kariyere ilișkin modelleme" ve "sözel teșvik" değișkenlerinin yanında "duygusal destek" değișkeni girmiştir. "araçsal yardım", "kariyere ilişkin modelleme", "sözel teşvik" ve "duygusal destek" değişkenleri birlikte öğrencilerin kariyer gelişimini \%8'sini $\left(\mathrm{R}=.286, \mathrm{R}^{2}=.082\right)$ açıklamaktadır.

Adımsal regresyon analizinin beşinci adımında modele "araçsal yardım", "kariyere ilişkin modelleme", "sözel teşvik" ve "duygusal destek" değişkenlerinin yanında "yaş", "gidilmek istenen lise türü" ve "bitirilmek istenen okul" değişkenleri girmiştir. "araçsal yardım", "kariyere ilişkin modelleme", "sözel teşvik", "duygusal destek", "yaş", "gidilmek istenilen lise türü” ve "bitirilmek istene okul" değişkenleri birlikte öğrencilerin kariyer gelişimini \%13'ünü $(\mathrm{R}=.356$, $\left.\mathrm{R}^{2}=.127\right)$ açıklamaktadır. Regresyon analizi sonuçlarına bakıldığında regresyon katsayıları, $\mathrm{R}^{2}$ ve t değerleri incelendiğinde sırasıyla "bitirilmek istenilen okul", "araçsal yardım", "duygusal destek", "yaş", "kariyere ilişkin modelleme", "sözel teşvik", "gidilmek istenen lise türü" değerlerine bakıldığında anlamlı olarak kariyer gelişimini yordadığı görülmektedir.

Tablo 4. Cinsiyete Göre Kariyer Gelişimi ve Ebeveyn Desteği Alt Ölçeklerine İlişkin $t$-Testi Sonuçları

\begin{tabular}{|c|c|c|c|c|c|c|c|}
\hline \multirow{6}{*}{$\begin{array}{l}\text { Çoçuklar İçin } \\
\text { Kariyer } \\
\text { Gelişimi } \\
\text { Ölçeği }\end{array}$} & Alt Ölçekler & & $N$ & $\bar{X}$ & Ss & $t$ & $p$ \\
\hline & \multirow{2}{*}{ Bilgi } & $\mathrm{K} 1 \mathrm{z}$ & 693 & 16.42 & 1.88 & \multirow{2}{*}{4.25} & \multirow{2}{*}{$.000^{*}$} \\
\hline & & Erkek & 595 & 15.73 & 1.98 & & \\
\hline & \multirow{2}{*}{ Merak } & Kız & 693 & 17.79 & 2.27 & \multirow{2}{*}{13.01} & \multirow{2}{*}{$.000^{*}$} \\
\hline & & Erkek & 595 & 16.69 & 2.57 & & \\
\hline & İlgi & $\mathrm{K} 1 \mathrm{z}$ & 693 & 16.63 & 1.85 & 3.96 & .372 \\
\hline
\end{tabular}




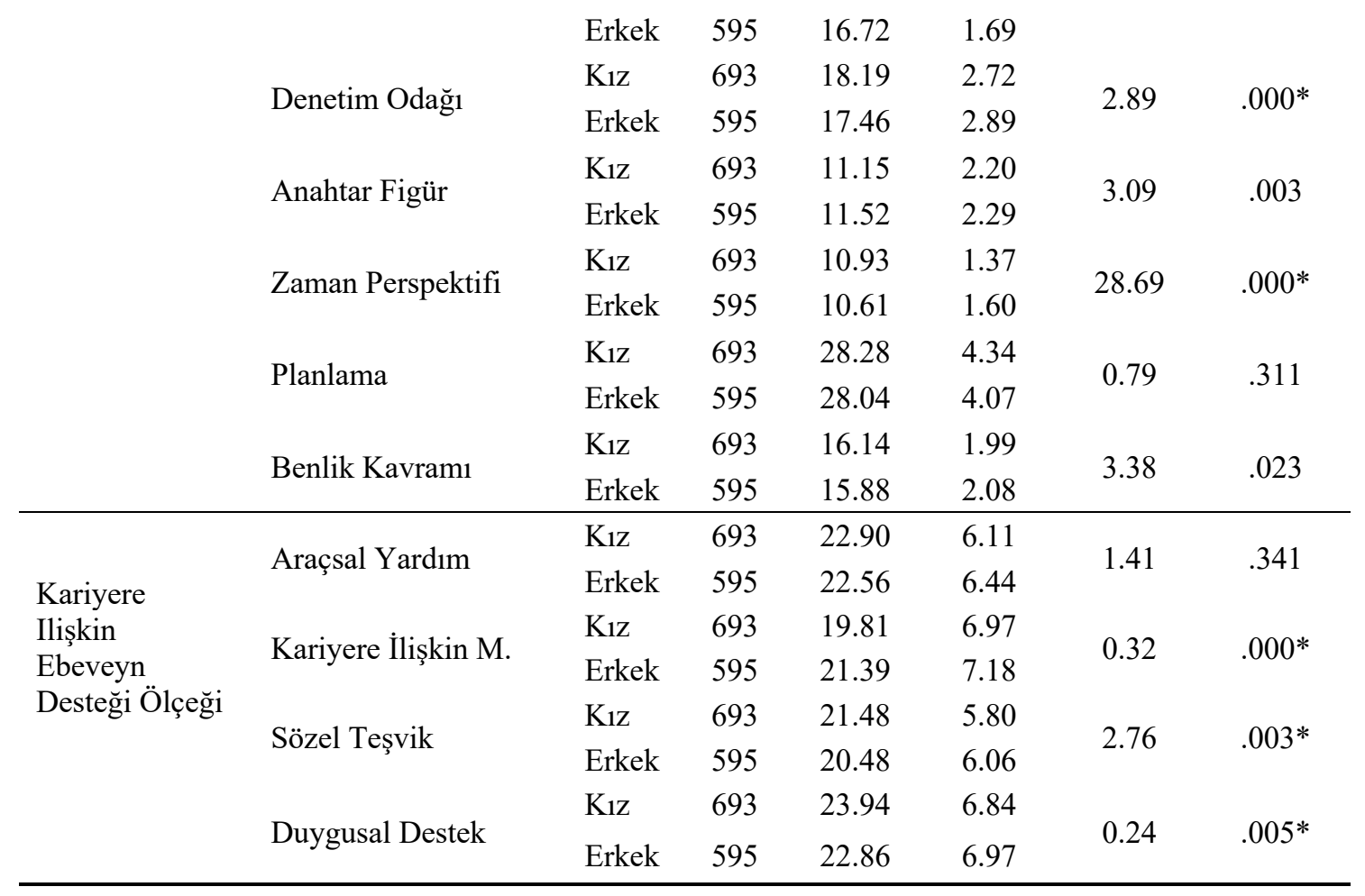

Tablo 4'te bağımsız örneklemler için uygulanan $t$-testi sonucunda cinsiyete ilişkin Çocuklar İçin Kariyer Gelişim Ölçeği ve Kariyere İlişkin Ebeveyn Desteği Ölçeği istatistik bilgileri verilmiştir. Analiz sonucuna göre ilgi $(t=3.96, p>.05)$, planlama $(t=0.79, p>.05)$ ve araçsal yardım $(t=1.41, p>.05)$ alt boyutları cinsiyete göre farklılaşmamaktadır. Kız öğrencilerin bilgi, merak, denetim odağı, zaman perspektifi, benlik kavramı, sözel teşvik ve duygusal destek alt boyutlarındaki puanları erkek öğrencilerden anlamlı düzeyde daha yüksektir. Erkek öğrencilerin ise anahtar figür ve kariyere ilişkin modelleme alt boyutlarındaki puanları kız öğrencilerden anlamlı düzeyde daha yüksektir.

Tablo 5. Sınıf Düzeyine Göre Kariyer Gelişimi ve Ebeveyn Desteği Alt Ölçeklerine Ilişkin $t$ Testi Sonuçları

\begin{tabular}{|c|c|c|c|c|c|c|c|}
\hline & Alt Ölçekler & & $N$ & $\bar{X}$ & Ss & $t$ & $p$ \\
\hline \multirow{16}{*}{$\begin{array}{l}\text { Çoçuklar için } \\
\text { Kariyer } \\
\text { Gelişimi Ölçeği }\end{array}$} & \multirow{2}{*}{ Bilgi } & 7.Sinif & 625 & 15.94 & 1.94 & \multirow{2}{*}{0.10} & \multirow{2}{*}{.004} \\
\hline & & 8.Sinif & 663 & 16.25 & 1.96 & & \\
\hline & \multirow{2}{*}{ Merak } & 7.Sinif & 625 & 17.29 & 2.40 & \multirow{2}{*}{0.95} & \multirow{2}{*}{.965} \\
\hline & & 8.Sinif & 663 & 17.28 & 2.54 & & \\
\hline & \multirow{2}{*}{ İlgi } & 7.Sinif & 625 & 16.69 & 1.84 & \multirow{2}{*}{2.14} & \multirow{2}{*}{.701} \\
\hline & & 8.Sinif & 663 & 16.65 & 1.72 & & \\
\hline & \multirow{2}{*}{ Denetim Odağ 1} & 7.Sinif & 625 & 17.52 & 2.94 & \multirow{2}{*}{4.62} & \multirow{2}{*}{$.000^{*}$} \\
\hline & & 8.Sinif & 663 & 18.17 & 2.67 & & \\
\hline & \multirow{2}{*}{ Anahtar Figür } & 7.Sinif & 625 & 11.23 & 2.23 & \multirow{2}{*}{0.68} & \multirow{2}{*}{.146} \\
\hline & & 8.Sinif & 663 & 11.41 & 2.27 & & \\
\hline & \multirow{2}{*}{ Zaman Perspektifi } & 7.Sinif & 625 & 10.70 & 1.52 & \multirow{2}{*}{3.46} & \multirow{2}{*}{.059} \\
\hline & & 8.Sinif & 663 & 10.86 & 1.46 & & \\
\hline & \multirow{2}{*}{ Planlama } & 7.Sinif & 625 & 28.17 & 4.15 & \multirow{2}{*}{0.05} & \multirow{2}{*}{.955} \\
\hline & & 8.Sinif & 663 & 28.16 & 4.28 & & \\
\hline & \multirow{2}{*}{ Benlik Kavramı } & 7.Sinıf & 625 & 15.98 & 2.11 & \multirow{2}{*}{3.57} & \multirow{2}{*}{.468} \\
\hline & & 8.Sinif & 663 & 16.06 & 1.96 & & \\
\hline
\end{tabular}




\begin{tabular}{lllllllll}
\hline & \multirow{2}{*}{ Araçsal Yardım } & 7.Sınıf & 625 & 23.13 & 6.05 & 3.09 & .030 \\
& & 8.Sınıf & 663 & 22.38 & 6.45 & & \\
Kariyere & Kariyere İlişkin M. & 7.Sınıf & 625 & 20.57 & 6.99 & 0.51 & .858 \\
Ilişkin & & 8.Sınıf & 663 & 20.50 & 7.22 & & \\
EbeveynDesteği & \multirow{2}{*}{ Sözel Teşvik } & 7.Sınıf & 625 & 21.28 & 5.75 & \multirow{2}{*}{3.22} & .132 \\
Ölçeği & & 8.Sınıf & 663 & 20.78 & 6.11 & & \\
& \multirow{2}{*}{ Duygusal Destek } & 7.Sınıf & 625 & 23.46 & 6.76 & & .914 \\
& & 8.Sınıf & 663 & 23.42 & 7.07 & 1.74 & \\
\hline
\end{tabular}

Tablo 5'te $t$-testi sonucuna göre sınıf düzeyine ilişkin Çocuklar İçin Kariyer Gelişim Ölçeği ve Kariyere İlişkin Ebeveyn Desteği Ölçeği' nin istatistiki bilgileri verilmiştir. Analiz sonucuna göre bilgi $(t=0.10, p<.05)$ ve denetim odağı $(t=4.62, p<.05)$ alt boyutlarında alınan puanlara göre sinıf düzeyinde anlamlı bir farklılık bulunmaktadır. 8.sınıf öğrencilerinin bilgi boyutu $(16,25)$ ve denetim odağ $(18,17)$ ortalamaları 7 .sınıf öğrencilerinin bilgi $(15,94)$ ve denetim odağ 1 $(17,52)$ ortalamalarından daha yüksektir. Sınıf düzeyi arttıkça bilgi ve denetim odağı düzeyinin arttığ 1 söylenebilir. Araçsal yardım alt boyutunda ise $7 . \sin ı$ ortalamaları $(23,13), 8$.sınıf $(22,38)$ ortalamalarından daha yüksek bulunmuştur.

Tablo 6. Bitirilmek İstenen Okul Türüne Göre Tek Yönlü Varyans Analizi (ANOVA)

\begin{tabular}{|c|c|c|c|c|c|c|c|}
\hline & Alt Ölçekler & $\begin{array}{c}\text { Varyansın } \\
\text { Kaynağı }\end{array}$ & $\begin{array}{l}\text { Kareler } \\
\text { Toplamı }\end{array}$ & $\mathrm{Sd}$ & $\begin{array}{c}\text { Kareler } \\
\text { Ortalamas1 }\end{array}$ & $\mathrm{F}$ & $p$ \\
\hline \multirow{16}{*}{$\begin{array}{c}\text { Çoçuklar İçin } \\
\text { Kariyer } \\
\text { Gelişimi } \\
\text { Ölçeği }\end{array}$} & \multirow{2}{*}{ Bilgi } & Gruplararası & 313.03 & 4 & 78.25 & 21.638 & .000 \\
\hline & & Grupiçi & 4640.17 & 1283 & 3.61 & & \\
\hline & \multirow{2}{*}{ Merak } & Gruplararası & 506.74 & 4 & 126.68 & 22.008 & .000 \\
\hline & & Grupiçi & 7385.39 & 1283 & 5.75 & & \\
\hline & \multirow{2}{*}{ İlgi } & Gruplararası & 158.92 & 4 & 39.73 & 12.963 & .000 \\
\hline & & Grupiçi & 3932.46 & 1283 & 3.06 & & \\
\hline & \multirow{2}{*}{ Denetim Odağ 1} & Gruplararası & 271.37 & 4 & 67.84 & 8.681 & .000 \\
\hline & & Grupiçi & 10026.91 & 1283 & 7.81 & & \\
\hline & \multirow{2}{*}{ Anahtar Figür } & Gruplararası & 6.05 & 4 & 1.51 & 0.297 & .880 \\
\hline & & Grupiçi & 6546.28 & 1283 & 5.10 & & \\
\hline & \multirow{2}{*}{$\begin{array}{l}\text { Zaman } \\
\text { Perspektifi }\end{array}$} & Gruplararası & 86.56 & 4 & 21.64 & 9.978 & .000 \\
\hline & & Grupiçi & 2782.57 & 1283 & 2.16 & & \\
\hline & \multirow{2}{*}{ Planlama } & Gruplararası & 376.83 & 4 & 94.20 & 5.354 & .000 \\
\hline & & Grupiçi & 22574.90 & 1283 & 17.59 & & \\
\hline & \multirow{2}{*}{ Benlik Kavramı } & Gruplararası & 124.50 & 4 & 31.12 & 7.655 & .000 \\
\hline & & Grupiçi & 5216.79 & 1283 & 4.06 & & \\
\hline \multirow{8}{*}{$\begin{array}{l}\text { Kariyere } \\
\text { Ilişkin } \\
\text { Ebeveyn } \\
\text { Desteği } \\
\text { Ölçeği }\end{array}$} & \multirow{2}{*}{ Araçsal Yardım } & Gruplararası & 1561.17 & 4 & 390.29 & 10.207 & .000 \\
\hline & & Grupiçi & 49058.82 & 1283 & 38.23 & & \\
\hline & \multirow{2}{*}{ Kar. İlişskin Mod. } & Gruplararası & 740.81 & 4 & 185.20 & 3.690 & .005 \\
\hline & & Grupiçi & 64387.00 & 1283 & 50.18 & & \\
\hline & \multirow{2}{*}{ Sözel Teşvik } & Gruplararası & 2509.91 & 4 & 627.47 & 18.723 & .000 \\
\hline & & Grupiçi & 42999.18 & 1283 & 33.51 & & \\
\hline & \multirow{2}{*}{ Duygusal Destek } & Gruplararası & 2655.85 & 4 & 663.96 & 14.421 & .000 \\
\hline & & Grupiçi & 59069.89 & 1283 & 46.04 & & \\
\hline
\end{tabular}

Tablo 6' da katılımcıların bitirilmek isten okul türü (lise, lisans, yüksek lisans ve doktora) grup bazında bilgi, merak, ilgi, denetim odağı, zaman perspektifi, planlama, benlik kavramı, 
araçsal yardım, kariyere ilişkin modelleme, sözel teşvik ve duygusal destek alt boyutlarında varyans analizi sonucunda anlamlı fark bulunmaktadır. Anahtar figür alt boyutunda ise $\mathrm{F}_{(4,1283)}=$ $0.297, p>.05$ istatiksel olarak bir farklılık bulunmamaktadır.

Tablo 7. Öğrencilerin Gitmek Istediği Lise Türüne Göre Tek Yönlü Varyans Analizi (ANOVA)

\begin{tabular}{|c|c|c|c|c|c|c|c|}
\hline & $\begin{array}{l}\text { Alt } \\
\text { Ölçekler }\end{array}$ & $\begin{array}{l}\text { Varyansın } \\
\text { Kaynağı }\end{array}$ & $\begin{array}{l}\text { Kareler } \\
\text { Toplamı }\end{array}$ & $\mathrm{Sd}$ & $\begin{array}{l}\text { Kareler } \\
\text { Ortalaması }\end{array}$ & $\mathrm{F}$ & $\mathrm{P}$ \\
\hline \multirow{16}{*}{$\begin{array}{l}\text { Çoçuklar } \\
\text { İçin Kariyer } \\
\text { Gelişimi } \\
\text { Ölçeği }\end{array}$} & \multirow[t]{2}{*}{ Bilgi } & Gruplararası & 158.62 & 5 & 31.72 & \multirow[t]{2}{*}{8.483} & \multirow[t]{2}{*}{.000} \\
\hline & & Grupiçi & 4794.58 & 1282 & 3.74 & & \\
\hline & \multirow[t]{2}{*}{ Merak } & Gruplararası & 347.56 & 5 & 69.51 & \multirow[t]{2}{*}{11.812} & \multirow[t]{2}{*}{.000} \\
\hline & & Grupiçi & 7544.57 & 1282 & 5.88 & & \\
\hline & \multirow[t]{2}{*}{ İlgi } & Gruplararası & 147.44 & 5 & 29.48 & \multirow[t]{2}{*}{9.586} & \multirow[t]{2}{*}{.000} \\
\hline & & Grupiçi & 3943.94 & 1282 & 3.07 & & \\
\hline & \multirow{2}{*}{$\begin{array}{l}\text { Denetim } \\
\text { Odağı }\end{array}$} & Gruplararası & 206.43 & 5 & 41.28 & \multirow[t]{2}{*}{5.245} & \multirow[t]{2}{*}{.000} \\
\hline & & Grupiçi & 10091.84 & 1282 & 7.87 & & \\
\hline & \multirow{2}{*}{$\begin{array}{l}\text { Anahtar } \\
\text { Figür }\end{array}$} & Gruplararası & 119.63 & 5 & 23.92 & \multirow[t]{2}{*}{4.769} & \multirow[t]{2}{*}{.000} \\
\hline & & Grupiçi & 6432.70 & 1282 & 5.01 & & \\
\hline & \multirow{2}{*}{$\begin{array}{l}\text { Zaman } \\
\text { Perspektifi }\end{array}$} & Gruplararası & 99.73 & 5 & 19.94 & \multirow[t]{2}{*}{9.234} & \multirow[t]{2}{*}{.000} \\
\hline & & Grupiçi & 2769.40 & 1282 & 2.16 & & \\
\hline & \multirow[t]{2}{*}{ Planlama } & Gruplararası & 738.44 & 5 & 147.68 & \multirow[t]{2}{*}{8.524} & \multirow[t]{2}{*}{.000} \\
\hline & & Grupiçi & 22213.29 & 1282 & 17.32 & & \\
\hline & \multirow{2}{*}{$\begin{array}{l}\text { Benlik } \\
\text { Kavramı }\end{array}$} & Gruplararası & 153.84 & 5 & 30.76 & \multirow[t]{2}{*}{7.604} & \multirow[t]{2}{*}{.000} \\
\hline & & Grupiçi & 5187.45 & 1282 & 4.04 & & \\
\hline \multirow{8}{*}{$\begin{array}{l}\text { Kariyere } \\
\text { Ilişkin } \\
\text { Ebeveyn } \\
\text { Desteği } \\
\text { Ölçeği }\end{array}$} & \multirow{2}{*}{$\begin{array}{l}\text { Araçsal } \\
\text { Yardım }\end{array}$} & Gruplararası & 1363.33 & 5 & 272.66 & \multirow[t]{2}{*}{7.097} & \multirow[t]{2}{*}{.000} \\
\hline & & Grupiçi & 49256.66 & 1282 & 38.42 & & \\
\hline & \multirow{2}{*}{$\begin{array}{l}\text { Kar. İlişkin } \\
\text { Mod. }\end{array}$} & Gruplararası & 926.43 & 5 & 185.28 & \multirow[t]{2}{*}{3.700} & \multirow[t]{2}{*}{.002} \\
\hline & & Grupiçi & 64201.38 & 1282 & 50.07 & & \\
\hline & \multirow{2}{*}{$\begin{array}{l}\text { Sözel } \\
\text { Teşvik }\end{array}$} & Gruplararası & 2299.19 & 5 & 459.83 & 13.643 & .000 \\
\hline & & Grupiçi & 43209.91 & 1282 & 33.70 & & \\
\hline & Duygusal & Gruplararası & 2037.38 & 5 & 407.47 & 8.752 & .000 \\
\hline & Destek & Grupiçi & 59688.35 & 1282 & 46.55 & & \\
\hline
\end{tabular}

Tablo 7'de öğrencilerin gitmek istediği lise türüne göre ölçeklerin alt boyutlarını incelemek amacıyla parametrik bir test olan Tek Yönlü Varyans Analizi uygulanmış olup istatiksel olarak anlamlı farklılık bulunmuştur. Farklılığın kaynağını tespit etmek amaciyla uygulanan Tukey testi uygulanmıştır. Varyans analizi sonucunda bilgi boyutu $\mathrm{F}(5,1282)=8.483, p<0.05$; merak boyutu $\mathrm{F}(5,1282)=11.812, p<0.05$; ilgi boyutu $\mathrm{F}(5,1282)=$ 9.586, $p<0.05$; denetim odağ 1 boyutu $\mathrm{F}(5,1282)=5.245, p<0.05$; anahtar figür boyutu $\mathrm{F}(5,1282)=4.769, p<0.05$; zaman perspektifi boyutu $\mathrm{F}(5,1282)=9.234, p<.05$; planlama boyutu $\mathrm{F}(5,1282)=8.524, p<.05$; benlik kavramı $\mathrm{F}(5,1282)=7.604, p<.05$; araçsal yardım boyutu $\mathrm{F}(5,1282)=7.097, p<.05$; kariyere ilişkin modelleme boyutu $\mathrm{F}(5,1282)=3.700, p<.05$; sözel teşvik boyutu $\mathrm{F}(5,1282)=13.643, p<.05$; duygusal destek boyutu $\mathrm{F}(5,1282)=8.752, p<$ .05 ; istatiksel olarak anlamlı farklılık hesaplanmıştır.

\section{TARTIŞMA, SONUÇ VE ÖNERILLER}

Bu çalışmada ilköğretim 7. ve 8. sınıf öğrencilerinin kariyer gelişiminde ebeveyn desteği ve sosyo-demografik değişkenlerin rolü incelenmiştir. Araştırmada, kariyer gelişimi cinsiyete 
göre incelendiğinde kız ve erkek öğrenciler arasında alt ölçekler olan bilgi, merak, ilgiler, denetim odağ kariyere ilişkin modelleme, sözel teşvik ve duygusal destek boyutlarında anlamlı bir farklılık görülmektedir. Araştırma sonuçları 7. ve 8. sınıflardaki kız öğrencilerin kariyer gelişimi düzeyinin, erkek öğrencilerin kariyer gelişim düzeylerinde yüksek olduğu sonucuna ulaşan (Sapmaz, 2010) araştırmayla benzerlik göstermektedir. Bununla birlikte 7. ve 8. sınıflardaki kız öğrenciler ile erkek öğrencilerin kariyer gelişimleri arasında fark olmadığını bulan (Can ve Tayl1, 2014; Yayla ve Bacanl1, 2011) araştırmalarla farklılık göstermektedir. Araştırmada, kız öğrencilerin bilgi, merak, denetim odağı, zaman perspektifi, benlik kavramı, sözel teşvik ve duygusal destek düzeylerinin erkek öğrencilerden yüksek olduğu görülmektedir. Ayrıca kız öğrencilerin mesleklere ilişkin bilgi düzeylerinin yüksek olması araştırmaya ve incelemeye daha çok teşvik eden bir yönlendirici unsur olmaktadır. Zaman algılarının yüksek olması geleceğe yönelik planlamalarda özgüvenlerinin etkisiyle içsel motivasyona katkıda bulunduğu söylenebilir. Erkek öğrencilerin ise anahtar figür ve kariyere ilişkin modelleme alt boyutlarında kız öğrencilere göre daha yüksek puanlara sahip olduğu görülmektedir. Kariyer gelişimi literatüre bakıldığında bazı araştırmaların (Luzzo, 1995; Rojewski, Wicklein, ve Schell, 1995) sonuçlarıyla aynı doğrultuda olduğu görülmektedir. Ancak bazı araştırmacılar ise (Watson, 1984; Bozgeyikli, Bacanlı, ve Doğan, 2009) cinsiyetler arası fark olmadığ s sonucuna ulaşmışlardır. Toplumsal cinsiyet algısı ve mesleklere ilişkin rol atıfları kadınların iş dünyasındaki sayılarının düşük olmasına neden olmakta; bu sebeple kız öğrencilerin anahtar figür ve kariyere ilişkin modelleme alt boyutlarında düşük puan aldıkları düşünülmektedir. $\mathrm{Bu}$ nedenle eğitim kurumlarında yapılan kariyer danışmanlığı uygulamalarında bu durum göz önüne alınarak kız öğrencilerin rol model alabilecekleri önemli başarılara imza atan kadın meslek çalışanlarına daha çok yer verilebilir.

Araştırmada 7. ve 8. sınıf düzeyine göre kariyer gelişimi incelendiğinde bilgi, denetim odağı ve araçsal yardım alt boyutlarında anlamlı farklılık bulunmaktadır. Bilgi ve denetim odağı boyutunda diğer araştırmalarda olduğu gibi (Bacanlı ve Sürücü, 2011; Can ve Taylı, 2014; Sapmaz, 2010) 8. sınıf öğrencilerin aldıkları puanların daha yüksek olduğu görülmektedir. Sınıf düzeyi yükseldikçe öğrencilerin mesleklere ilişkin bilgilerinin ve kariyer sürecini kontrol derecelerinin arttığı söylenebilir. Araçsal yardım boyutunda ise 7. sınıf öğrencilerinin aldıkları puanlar daha yüksek görülmektedir. Sınıf düzeyi ve öğrencilerin farkındalıkları arttıkça desteğe duyulan ihtiyacın azaldığı söylenebilir. Sonuçlardan hareketle çeşitli aile eğitimleri düzenlenerek ya da ailelere ev ziyaretleri yapılarak daha alt sınıflarda çocuklarına nasıl destek sağlayacakları konusunda seminer, konferans ve atölye çalışmaları yapılabilir. Sınıf düzeyi ilerledikçe çocukların bilgi ve denetim odağı düzeyleri arttığından dolayı ebeveyn desteği çocuğun bağımsızlığını engellemeden dengeli bir şekilde sunulmalıdır. İlerleyen yaşlarda çocukların yaptıkları tercihlerin sonuçlarıyla başa çıkabilmeleri için basit kararlarda seçim hakkı tanınmalıdır.

Öğrencilerin gitmek istediği lise türüne göre kariyer gelişimi ve alt boyutları incelendiğinde en yüksek puanların sırasıyla fen lisesi, anadolu/imam hatip lisesi ve meslek lisesi olduğu görülmektedir. Merkezi sınav ile öğrenci alan okulların akademik başarısı ile kariyer gelişimi arasında doğru orantı olduğu söylenebilir. Okulların akademik başarısı arttıkça öğrencilerin hedefleri olgunlaşmakta ve nihai hedeflerine ulaşma çabası disiplinli çalışma gerektirdiği için içsel motivasyon düzeylerinde etkili olmaktadır. Bunun yanında akademik başarı arttıkça ebeveyn beklentilerinin oluşmasıyla daha etkin destek yöntemlerini kullanılmaktadır (Güneş, 2015). Öğrencinin akademik başarısı düştükçe aileler çocuklarına olan umutlarını kaybetmekte ve yeterli bilince sahip değilse çeşitli iş kollarına yönlendirebilmektedir. Bu nedenle ailelerin koşulsuz kabul ilkesini benimseyerek hangi süreçte olursa olsun azimli bir duruş sergileyerek çocuklarının ilgi ve yetenekleri doğrultusunda gerekli yönlendirmeleri yapmaları gerekmektedir. Eğitim kurumları ve ebeveynler nitelikli okul öngörüsünden kurtularak çocuklara en iyi şartları sağlamalıdır. Her eğitim kademesinde ve okul türünde 
ebeveynlerin de dâhil edildiği kariyer günleri düzenlenmeli, meslek elemanları ve iş dünyası ile çocuklar buluşturulmalıdır.

Araştırma sonuçları en son bitirilmek istenen okul türüne göre incelendiğinde doktora programlarını bitirmek isteyen öğrencilerin sadece lise mezunu olmak isteyen öğrencilere göre kariyer gelişim düzeylerinin daha yüksek olduğu görülmektedir. Kişilik özellikleri ve çevresel faktörlerin etkili olduğu kariyer gelişim sürecinde planlı, düzenli, azimli, disiplinli ve ideal çerçevesinde çalışan bireylerin kariyer gelişim düzeylerinin daha yüksek olduğu söylenebilir (Yerin Güneri, Owen, Tanrıkulu, Dolunay-Cuğ ve Buyukgoze-Kavas, 2016). Eğitim öğretim sürecine bakıldığında iyi bir ilköğretim süreci demek iyi bir lise demektir; iyi bir lise iyi bir üniversite ve lisansüstü eğitim olduğu varsayımı toplum tarafindan kabul edilen bir olgudur. Bu nedenle ilköğretim sürecinin etkisi anlaşılmakla birlikte kariyer basamaklarında eğitim öğretim süreci öne çıkmaktadır. Bireylerin kişisel özellikleri meslek tercihlerini etkilemekle birlikte meslek tercihleri de kişinin çevresini ve toplumsal rollerini belirlemektedir (Kuzgun, 2008; Vurucu, 2010). Bu nedenle ilköğretim döneminden itibaren çocukların üst eğitim kurumlarını tanımalarına yönelik çalışmalar yapılmalıdır. Böylelikle küçük yaşlarda itibaren çocukları her kademedeki eğitim kurumlarının şartlarını, yeterliliklerini, koşullarını ve çıktılarını öğrenerek daha iyi planlamalar yapabilir.

Kariyer psikolojik danışmanlığı, bireylerin yeteneklerini, ilgilerini, değerlerini, kişisel özelliklerini, ihtiyaçlarını ve gelişim dönemlerini dikkate alan profesyonel bir süreç olması sebebiyle günümüzde ihtiyaç hissedilen uzmanlık alanıdır (Bacanlı ve Torun, 2012; Korkut Owen, 2018; Sert Ağır, 2017). Bu bağlamda kariyer gelişiminde çocuğun hayata gözlerini açtı̆g 1 ilk toplumsal kurum olan aile, kariyer gelişimi sürecinde önemli bir çevresel faktördür. Kariyer gelişiminin her aşamasında çocuk üzerinde görülen anne baba etkisi kariyer psikolojik danışmanlığı açısından da güvenilir bir kaynak niteliği taşımaktadır. Bu nedenle ebeveyn ve çocukların sağlıklı iletişim kurmaları ve anne babaların çocukların kariyer basamaklarındaki ilerleyişte farkındalıklarını sağlamak amacıyla kariyere yönelik aile eğitimleri planlanabilir. Özellikle okul-aile ilişkisi güçlendirilerek bilimsel çalışmalara yön verilebilir. Bu doğrultuda ilköğretim öğrencilerinin kariyer gelişimlerine yönelik ana sınıfından itibaren ilköğretimin sonu olan 8.sınıf öğrencilerini kapsayacak biçimde geniş çaplı çalışmaların yapılması alana ve uygulayıcılara önemli katkılar sağlayacaktır. Bununla beraber ileride yapılacak çalışmalarda çocukların kariyer gelişimini etkileyen psikolojik, sosyolojik, ekonomik ve politik birçok değişken açısından incelenmesi alana önemli katkılarda sağlayacaktır.

\section{KAYNAKÇA}

Akkoç, F.F. (2009). Lise öğrencilerinin kariyer düşüncelerini etkileyen faktörlerin incelenmesi. (Yayımlanmamış Doktora Tezi). Dokuz Eylül Üniversitesi Eğitim Bilimleri Enstitüsü, İzmir.

Alkan, N. (2014). Üniversite adaylarının bölüm tercihleri: bir kariyer araştırma yöntemi olarak bölüm tanıtımları. Türk Psikolojik Danışma ve Rehberlik Dergisi, 41(5), 61-74.

Altay Köse, T., ve Yangın, S. (2015). İlkokul ve ortaokul öğrencilerinin bilimsel kariyer ilgileri. Recep Tayyip Erdoğan Üniversitesi Sosyal Bilimler Dergisi, 1, 45-66.

Aslan, Ş., Yalçın, H., Sarp, N., ve Akarçay Uluçay, D. (2018). Anne-baba davranışlarının ve sosyal çevrelerinin liderlere etkileri. Üsküdar Üniversitesi Sosyal Bilimler Dergisi, 3(4), 91-138.

Bacanl1, F., ve Sürücü, M. (2011). İlköğretim öğrencilerinin kariyer gelişimleri ile ebeveyne bağlanmaları arasındaki ilişkilerin incelenmesi. Türk Ĕgitim Bilimleri Dergisi, 9(4), 679700 . 
Bacanlı, F., ve Torun, S. (2012). İlköğretim Öğrencileri Bazı Mesleklerin Tanıtımı. İlköğretim Online, 11(1), 230-238.

Bacanlı, F., Özer, A., ve Sürücü, M. (2006). Çocuklar için kariyer gelişim ölçeğinin faktör yapısı ve güvenirliği. 9. Ulusal Psikolojik Danışma ve Rehberlik Kongresi, İzmir.

Bozgeyikli, H., Bacanlı, F., ve Doğan, H. (2009). İlköğretim sekizinci sınıf öğrencilerinin mesleki karar verme yetkinliklerinin yordayıc1larının incelenmesi. Selçuk Üniversitesi Sosyal Bilimler Enstitüsü Dergisi, 21, 125-136.

Can, A., ve Taylı, A. (2014). Ortaokul öğrencilerinin kariyer gelişimlerinin incelenmesi. Abant İzzet Baysal Üniversitesi Ĕ̈itim Fakültesi Dergisi, 14(2), 321-346.

Dinç, E. (2008). Meslek seçiminde etkili olan faktörlerin incelenmesi: Meslek yüksekokulu muhasebe programı öğrencileri üzerine bir araştırma. Kocaeli Üniversitesi Sosyal Bilimler Enstitüsü Dergisi, 2(16), 90-106.

Eryılmaz, A., ve Mutlu, T. (2017). Yaşam boyu gelişim yaklaşımı perspektifinden kariyer gelişimi ve ruh sağlığı. Psikiyatride Güncel Yaklaşımlar-Current Approaches in Psychiatry, 9(2), 227-249.

Gelişli, Y., Kazykhankyzy, L., ve Shauyenova, M. (2018). İlköğretim sekizinci sınıf öğrencilerinin meslek seçimine etki eden değerler (Mardin ili örneği). İlköğretim Online, 17(4), 2216-2228.

Ginzberg, E., Ginsburg, S.W., Axelrad, S., ve Herma, J. (1951). Occupational choice: An approach to a general theory. New York: Columbia Universty Press.

Güneş, A. (2015). Kariyere ilişkin ebeveyn desteği ölçeği'nin Türkçeye uyarlaması. (Yüksek Lisans Tezi). Gazi Üniversitesi Eğitim Bilimleri Enstitüsü, Ankara.

Işık, E. (2014). Çocuk kariyer gelişimi ile yaşam doyumu ve durumluk kaygı arasındaki ilişkilerin incelenmesi. Illkögretim Online, 13(2), 682-693.

Kapıkıran, Ş. (2016). Ebeveyn akademik başarı baskısı ve desteği ölçeğinin psikometrik değerlendirmeleri ve yapısal geçerlik: ortaokul ve lise öğrencileri. Ege Eğitim Dergisi, $17(1), 62-83$.

Kesici, Ş. (2005). Ortaöğretim öğrencilerinin anne baba tutumlarının ve rehberlik ihtiyaçlarının mesleki karar verme zorluklarını yordaması. Selçuk Üniversitesi Sosyal Bilimler Enstitüsü Dergisi, 10(2), 329-339.

Korkut Owen, F. (2018). Üniversite öğrencilerinin kariyer gelişim ihtiyaçları. Yaşadıkça Eğitim Dergisi, 32(2), 28-39.

Kuzgun, Y. (2008). Meslek danışmanlı̆̆ı: kuramlar uygulamalar. Nobel Yayınları, Ankara.

Luzzo, D.A. (1995). The relationship between career aspiration-current occupation congruence and the career maturity of undergraduates. Journal of Employment Counseling, 32, 132140 .

McMahon, M., ve Watson, M. (2008). Children's career development: Status quo and future directions. The Career Development Quarterly, 57, 4-6.

Nalbantoğlu Yılmaz, F., ve Çetin Gündüz, H. (2018). Lise öğrencilerinin kariyer kaygılarının çeşitli değişkenlere göre incelenmesi. Abant İzzet Baysal Üniversitesi Ĕgitim Fakültesi Dergisi, 18(3), 1585-1602.

Özdemir Yaylacı, G. (2007). İlköğretim düzeyinde kariyer eğitimi ve danışmanlığı. Bilig, 40, 119140.

Özgüven, İ.E. (2003). Endüstri Psikolojisi. Pdrem Yayınları, Ankara. 
Öztemel, K. (2013). Lise öğrencilerinin kariyer karar verme güçlüklerinin yordayıcıları olarak algilanan sosyal destek ve cinsiyet. Türk Eğitim Bilimleri Dergisi, 11(3), 241-257.

Özyürek, R. (2013). Kariyer Psikolojik Danışma Kuramları: Çocuk ve Ergenler İçin Kariyer Rehberliği Uygulamaları. Nobel Yayınları, Ankara.

Pekkaya, M., ve Çolak, N. (2013). Üniversite öğrencilerinin meslek seçimini etkileyen faktörlerin önem derecelerinin AHP ile belirlenmesi. International Journal of Social Science, 6(2), 797-818.

Pişkin, M. (2012). Kariyer gelişim sürecini etkileyen faktörler. B. Yeşilyaprak içinde, Mesleki rehberlik ve kariyer danışmanlığı: kuramdan uygulamaya (s. 43-87). Pegem Akademi, Ankara.

Rojewski, J.W., Wicklein, R.C., ve Schell, J.W. (1995). Effects of gender and academic risk behaviour on the career maturity of rural youth. Journal of Research in Rural Education, $11,92-104$.

Sapmaz, H.İ. (2010). İlköğretim II. kademe ögrencilerinin kariyer gelişim düzeyleri ile ilgi ve yetenekleri arasındaki iliş̧kinin incelenmesi (kesitsel bir çalışma). (Yayımlanmamış Yüksek Lisans Tezi). Gazi Üniversitesi Eğitim Bilimleri Enstitüsü, Ankara.

Sert Ağır, M. (2017). Eğitsel rehberlik çalışmalarının önemi. HAYEF: Journal of Education, 14(2), 183-202.

Super, D. (1990). A Life Span, Life Space Approach to Career Development. D. Brown, ve L. Brooks içinde, Career Choice and Development: Applying Contemporary Theory to Practice (s. 197-261). San Francisco: Jossey-Bass.

Şeker, G., ve Kaya, A. (2018). Lise öğrencilerinin meslek seçiminde aile desteği: bir ölçek geliştirme çalışması. Türk Psikolojik Danışma ve Rehberlik Dergisi, 49, 157-171.

Tuzcuoğlu, S. (2000). Benlik ve mesleki benlik kavramlarının öğretim yılları ile ilişkisi. M. Atatürk Ĕgitim Fakültesi Eğitim Bilimleri Dergisi, 12, 267-280.

Vurucu, F. (2010). Meslek lisesi öğrencilerinin meslek seçimi yeterliliği ve meslek seçimini etkileyen faktörler. (Yayımlanmamış Yüksek Lisans Tezi). Yeditepe Üniversitesi Sosyal Bilimler Enstitüsü, İstanbul.

Yayla, A., ve Bacanlı, F. (2011). İlköğretim 8.sınıf öğrencilerinin kariyer gelişimleri ile karar verme stilleri arasındaki ilişkinin incelenmesi. Illköğretim Online, 3(10), 1148-1159.

Yerin Güneri, O., Owen, D., Tanrıkulu, İ., Dolunay Cuğ, F.,\& Buyukgoze-Kavas, A. (2016). Eğitim Fakültesi öğrencilerinin kariyer gelişimi ihtiyaçlarının incelenmesi. Eğitimde Kuram ve Uygulama, 12, 178-193.

Watson, M.B. (1984). Career development of coloured high school pupils. Unpublished doctoral dissertation, University of Port Elizabeth, Port Elizabeth.

Whiston, S.C., ve Keller, B.K. (2004). The Influences of the Family of Origin on Career Development: A Review and Analysis. The Counseling Psychologist, 32(4), 493-568. https://doi.org/10.1177/

\section{EXTENDED ABSTRACT}

According to the NCDA, "career counseling provides the opportunity for a deeper level involvement with the client based on the establishment of a professional counseling relationship and the potential for assisting clients with career and personal concern beyond those included in career planning" $(2015$, p.3). The career development process guides the determination of 
decision-making and road-mapping about careers like the individual gaining awareness, learning about educational opportunities, discovering interests and abilities, and assessing work opportunities about the future and aims to assist in acquiring a variety of skills about these important topics (Özyürek, 2013).

Though the career development process appears to begin with the birth of an individual and continue until death (Ginzberg, 1951; Super, 1990), studies about career development in the period before high school appear to be very limited in Turkey (Altay Köse, \& Yangın, 2015; Bacanl1, \& Sürücü, 2011; Bozgeyikli, Bacanlı, \& Doğan, 2009; Can, \& Taylı, 2014; Gelişli, Kazykhankyzy, \& Shauyenova, 2018; Işık, 2014; Özdemir Yaylac1, 2007). Research about career development appears to focus more on high school and university students (Akkoç, 2009; Alkan, 2014; Dinç, 2008; Korkut Owen, 2018; Nalbantoğlu Yılmaz, \& Çetin Gündüz, 2018; Öztemel, 2013; Pekkaya Çolak, 2013; Şeker, \& Kaya, 2018). If children can look from a life-long development perspective on the career development process, it will contribute to problems experienced in career development and solve these problems and provide positive support for mental health (Eryılmaz \& Mutlu, 2017).

A numerous factors affect career development in childhood (Bacanl1, \& Torun, 2012). Leading these factors are the family, qualified as the smallest construction stone in society. The family's economic status, demographic characteristics, educational levels of family members led by mother and father, socioeconomic and cultural features of the family, and their environment may positively or negatively affect career development (Whiston, \& Keller, 2004). The number of siblings in the family, ages of children, communication style within the family, and attitudes of mother and father are other effective elements. It appears that the attitudes of mother and father are critical in terms of directing the occupational decision-making process, collecting information, motivation, providing enriching stimulation and experiences (Bell, Allen, Hauser, \& O'Connor, 1996; Kesici, 2005; Whiston, \& Keller, 2004).

In addition to family traits, the individual's sex is one of the factors affecting career development. When examined from this aspect, compared with men, the numbers of women in areas like engineering, mechanical, manufacturing industries, and management jobs display significant differences (Korkut-Owen, \& Mutlu, 2016; Özyürek, 2013). This differentiation in labor employment is affected by societal gender roles, societal judgments, and traditional thinking (Gökcan, \& Büyükgöze Kavas, 2018). In short, factors affecting career development in children may be classified as psychological, sociological, sex, economic, and political factors (Pişkin, 2012).

In Turkey, we see limited studies when we look at the relevant literature equivalent to the primary teaching period, a part of the mandatory education policy. As a result, this research aimed to investigate the roles of parental support and sociodemographic variables in the career development of $7^{\text {th }}$ and $8^{\text {th }}$ class primary education students. Additionally, career development levels of children were investigated in terms of gender, class, age, the number of siblings, motherfather status, income level, type of high school they wish to attend and final graduation level they wish to achieve.

The research was performed to investigate career development levels of primary education $7^{\text {th }}$ and $8^{\text {th }}$ class students with parental support and aspects like sex, class level, number of siblings, age, parents living together/separated/alive, socioeconomic level income status, secondary education organization they wished to attend and final educational degree they hoped to achieve. The research collected data using a descriptive model with sample selection made using the simple random sampling method. The study group for the research comprised a total of 1288 students (693 girls, 292 boys) attending $7^{\text {th }}$ and $8^{\text {th }}$ class in 12 different middle schools in the provincial county sector during the 2017-2018 educational year.

In this study, to access sociodemographic information about $7^{\text {th }}$ and $8^{\text {th }}$ class students in primary education, a personal information form was used, the Career Development Scale for 
Children (CDSC; Bacanl, Özer, \& Sürücü, 2006) was used for career development levels and the Career-related Parental Support Scale (CPSS; Güneş, 2015) was used to measure parental support. Data were transferred to a computer by the researcher using SPSS 22 program and prepared for data analysis. As a result of normality analysis, the research was completed with data from 1288 students. Descriptive statistics in the research were obtained as numerical values showing sociodemographic distributions by calculating frequencies/percentages. To compare binary group variables in the research, the independent samples $t$-test was used, while the one-way Analysis of Variance (ANOVA) was used to compare more than two groups. Analysis additionally calculated the Pearson correlation coefficients.

When regression analysis results and regression coefficients, $\mathrm{R}^{2}$ and $\mathrm{t}$ values are investigated, career development was significantly predicted by the values of degree they wished to achieve "instrumental aid", "emotional support", "age", "career-related modeling", "verbal encouragement" and "high school they wished to attend". According to the $t$-test for independent samples, the subdimensions of interest $(t=3.96, p>.05)$, planning $(t=0.79, p>.05)$ and instrumental assistance $t=1.41, p>.05)$ did not differ according to sex. The points for the subdimensions of knowledge, curiosity, control focus, time perspective, self-concept, verbal encouragement, and emotional support for female students were significantly higher than male students. Male students had significantly higher points for the subdimensions of key figure and career-related modeling compared to female students. According to $t$-test results, the points for the subdimensions of information $(t=0.10, p<.05)$ and control focus $(t=4.62, p<.05)$ were found to be significantly different according to class level. The mean values for the information dimension (16.25) and control focus (18.17) for $8^{\text {th }}$ class students were higher than the mean for information (15.94) and control focus (17.52) for $7^{\text {th }}$ class students. As class level increased, information and control focus levels can be said to increase. The subdimension of instrumental assistance had higher mean for $7^{\text {th }}$ class students (23.13) compared to $8^{\text {th }}$ class students (22.38). When participants are grouped based on type of degree they wished to achieve (high school, undergraduate, masters and doctorate), variance analysis results found significant differences for information, curiosity, interest, control focus, time perspective, planning, self-concept, instrumental assistance, career-related modeling, verbal encouragements, and emotional support subdimensions. For the key figure subdimension, there was no statistical difference $\left(\mathrm{F}_{(4,1283)}=\right.$ $0,297, p>.05)$. The one-way Analysis of Variance was applied as the parametric test with the aim of investigating the subdimensions of the scales according to the high school students wished to attend, and statistically significant differences were found. The Tukey test results, applied to identify the source of the difference, found differences for information, curiosity, interest, control focus, key figure, time perspective, planning, self-concept, instrumental assistance, career-related modeling, verbal encouragement, and emotional support subdimensions according to the type of high school students wished to attend.

In the research, when career development is investigated according to sex, there were significant differences observed between female and male students. The research results were similar to the conclusion that female students had higher career development levels than male students (Sapmaz, 2010), while they were different from research that found no difference in terms of career development (Can, \& Tayl1, 2014; Yayla, \& Bacanl1, 2011). Female students appeared to have higher information, curiosity, control focus, time perspective, self-concept, verbal encouragement, and emotional support levels compared to male students. According to the results, verbal and emotional support from mothers and fathers appear to be very effective in female students' career development compared to male students. When the research is investigated according to career development at $7^{\text {th }}$ and $8^{\text {th }}$ class level, there were significant differences for the control focus and instrumental assistance subdimensions. Just as in other research (Bacanl1, \& Sürücü, 2011; Can, \& Tayl1, 2014; Sapmaz, 2010), the information and control focus dimensions appear to have higher points among $8^{\text {th }}$ class students. As class level increases, students can be said to have increased information about occupations and increased control of the career process. The instrumental assistance dimension appeared to have higher 
points for $7^{\text {th }}$ class students. When career development and subdimensions are investigated according to the type of high school students wished to attend, the highest points were observed for science high school, Anatolia/imam hatip (religious) high school, and vocational high school. When the research results are investigated according to a type of degree students wished to achieve, students who wished to complete doctorate programs were observed to have higher career development levels than students who only wished to graduate from high school. It can be said that individuals who approach the career development process, affected by personality traits and environmental factors, within a planned, organized, resolute, disciplined, and ideal framework have higher career development levels.

Career counseling is a professional process noting the abilities, interests, values, personality traits, needs, and development periods of individuals (Sert Ağır, 2017). Career development dynamics in the childhood period have the quality of being a reliable reference contributing to the career development process. As a result, performing broad-scale studies to encompass the career development of primary education students from preschool up to $8^{\text {th }}$ class will provide significant contributions to the field and practitioners. 